ISSN 1027-5495. Functional Materials, 23, No.2 (2016), p. 326-330

doi:http://dx.doi.org/10.15407/fm23.02.326

(C) 2016 - STC “Institute for Single Crystals"

\title{
Three-dimensional finite element model generation based on CT image for concrete crack
}

\author{
Niu Wenjie ${ }^{1}, X u$ Qingqing ${ }^{1}, X u$ Ying $^{2}, X u$ Guohui $^{1}$, \\ Wang Xiaobin ${ }^{1}$, Zheng Shipo ${ }^{1}$, Liu $\mathrm{He}^{1}$
}

\author{
${ }^{1}$ School of Mechanical and Electronic Engineering, China University of \\ Petroleum(East China), Shandong, Qingdao, 266580, P.R. China \\ ${ }^{2}$ Sanying Precision Instruments Ltd, Shandong, Dongying, \\ 257091, P.R. China \\ Received January 27, 2016
}

\begin{abstract}
A generation method of three-dimensional finite element model based on CT image for concrete crack is proposed. Aiming at concrete crack, firstly, the paper adopts watershed algorithm to achieve the segmentation of CT image for concrete crack and uses Canny operator to extract the crack edges. Secondly, by using Marching Cubes algorithm the three-dimensional surface model for concrete crack is constructed. Finally, on the basis of three-dimensional surface model, the paper employs constrained Delaunay triangulation (CDT) algorithm to generate threedimensional finite element model for concrete crack. In the paper, the finite element method (FEM) software ABAQUS is used to achieve the analysis of loading for crack regions. The results show that this proposed method can achieve three-dimensional finite element model generation of concrete structures and mechanical analysis for the cracks which significantly improve the accuracy and efficiency of numerical simulation for the concrete structures.
\end{abstract}

Keywords: Concrete crack, CT image, three-dimensional finite element model.

Предложен метод генерации трёхмерной конечно-элементной модели, основанной на компьютерной томографии (КТ) изображения трещины. Показано, что изучение трещин позволяет адаптировать алгоритм водораздела для совершения сегментации КТизображения трещины и использовать оператор Кэнни для извлечения границ трещины. С использованием алгоритма "шагающих кубиков" построена трёхмерная модель поверхности трещины. На основе трёхмерной модели поверхности применяется алгоритм ограниченной триангуляции Делоне для генерации трёхмерной конечно-элементной модели трещины. Используется программа ABAQUS для анализа нагружения области трещины. Показано, что с помощью предложенного метода можно выполнить генерацию трёхмерной конечноэлементной модели структур и механический анализ трещин со значительным улучшением точности и эффективности численного моделирования структур.

Генерація тривимірної звичайно-елементної моделі, заснована на комп'ютерній томографії зображенні тріщини. Ніу Венжіе, Ху Квінкінг, Ху Яінг, Ху Гуохуі, Ванг Хіаобін, Женг Шіпо, Ліу Хе

Запропоновано метод генерації тривимірної звичайно-елементної моделі заснованої на комп'ютерній томографрії (КТ) зображення тріщини. Показано, що вивчення тріщин дозволяе адаптувати алгоритм вододілу для здійснення сегментації КТ-зображення тріщини і використовувати оператора Кенні для витягання меж тріщини. 3 використанням алгоритму “крокуючих кубиків" побудована тривимірна модель поверхні тріщини, на основі тривимірної моделі поверхні застосовуеться алгоритм обмеженої тріангуляції Делоне для генерації тривимірної звичайно-елементної моделі тріщини. Для анализу навантаження області тріщіни використовувавлась програма ABAQUS. Показано, що за допомогою запропонованого методу можна виконати генерацію тривимірних звичайноелементних моделі структур і механічний аналіз тріщин із значним поліпшенням точності та ефективності чисельного моделювання структур. 


\section{Introduction}

The concrete is a heterogeneous material which is cemented by the hardened cement and mortar. As the load conditions change, the concrete is gradually destroyed with the concrete crack extending. And the evolution of concrete crack initiation, propagation and extension is influenced by many factors, such as the performance of concrete, loading conditions and aggregate shape [1]. It is very difficult to observe the evolution of crack in concrete or analyze the loading of crack regions in the process of concrete physical experiment. In order to study the propagation, damage mechanism and loading statement of crack regions more conveniently, the numerical simulation method can be used to solve the problems [2].

With the development of computer technology and computational science, the status of numerical study in the field of geotechnical engineering is becoming more important. As the numerical simulation technology has the advantages of not being limited by the instrument which can be repeated for the test, it is of great significance to use the numerical simulation method to analyze and study the mechanical properties of concrete structures [3]. However, inaccurate numerical models can cause great errors in the results of numerical simulation. And there is not yet a mature method for the three-dimensional model generation of concrete crack [4]. In order to achieve the analysis of loading for crack regions and expand the application scope of numerical simulation method to concrete crack, it is necessary to propose a more accurate method to achieve the generation of three-dimensional finite element model for concrete structures [5].

In this paper, a generation method of threedimensional finite element model based on CT image for concrete crack is proposed. The three-dimensional surface model for concrete crack is constructed by extracting the voxels from CT images after crack detection and the three-dimensional finite element model for concrete crack is generated which is constrained by its three-dimensional surface model. The three-dimensional finite element model has included finite element with good quality, which can be directly imported into the FEM software ABAQUS through data interface. The numerical analysis and calculation of loading for crack regions are achieved by modifying the material parameters, load size and boundary conditions in ABAQUS.

\section{Three-dimensional finite element model generation}

This paper studies a concrete specimen whose three-dimensional finite element model is generated with the CT image sequence of 20 pixels per micron in image resolution. In order to show the three-dimensional finite element model of concrete crack more clearly, we select 53 consecutive pieces of CT images which include crack to generate the three-dimensional finite element model for concrete crack. The model generation is achieved based on a software platform that includes functions of voxels extraction and model generation written in $\mathrm{VC}++$ language.

\subsection{Voxels Extraction based on CT} image

CT Image Preprocessing. Before the voxels extraction, the CT image should be preprocessed to reduce the image noise or other interference factors to lay a good foundation for the voxels identification and extraction of next step. At present, the algorithm of image segmentation mainly includes threshold segmentation algorithm and watershed algorithm etc. [6] In this regard, the watershed algorithm [7] which is suitable for large data processing and has high efficiency and accuracy is adopted for image segmentation in this paper. And the algorithm implementation processes [8] are as follows:

1. The CT image is simplified by using grayscale erosion operation and gray-scale dilation operation to reduce image noise

Let $A$ denote the image simplification window and let $A_{x, y}$ denote the translation of $A$. And the origin is $(x, y)$.

Then the corrosion operator $\varepsilon_{A}(B)$ of the image $B$ is:

$$
\varepsilon_{A}(B)(x, y)=(x, y)=\min _{(k, l) \in B_{x, y}} B(k, l)
$$

And the expansion operator $\delta_{A}(B)$ is:

$$
\delta_{A}(B)(x, y)=(x, y)=\max _{(k, l) \in B_{x, y}} B(k, l)
$$

2. The morphological gradient $\mathrm{g}(x, y)$ of gray scale image is

$$
\mathrm{g}(x, y)=\varepsilon_{A}(B)(x, y)-\delta_{A}(B)(x, y)
$$

3. The segmentation of CT image is achieved based on gradient. The image after segmented $f_{B}(f)$ is

$$
f_{B}(f)=g(x, y) \times g(x, y) / 255.0
$$

After the above steps, the CT image is segmented into binarization image finally by using watershed algorithm and the result of segmentation is shown in Fig. 1. 

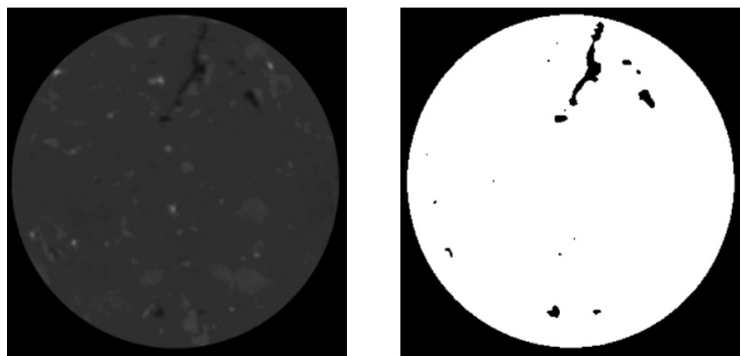

Fig. 1. CT image and binarization image of concrete.
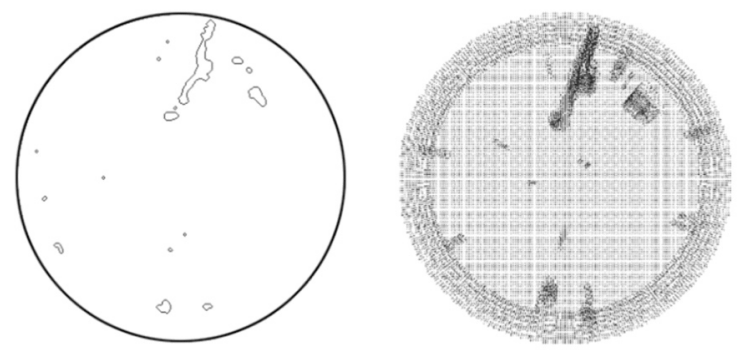

Fig. 2. The results of crack identification and voxels extraction.

Crack Identification and Voxels Extraction. In order to obtain the data of crack edges, it is necessary to detect the crack edges from binarization image. At present, the commonly used detection operators are Sobel operator, Laplacian operator and Canny operator, etc. Among these detection operators, the Canny operator is a multistage optimization operator with the functions of image filtering, image enhancement and image detection which has advantages of high noise-signal ratio and high detection accuracy [9]. In this paper, the Canny operator is adopted to detect and identify the crack edges, and the identification result is shown in Fig. (2).

In order to extract the voxels from CT image, we use the voxels extraction software which written by our research group to identify crack edges and extract voxels. Let $(X, Y, Z)$ denote the voxel that $X, Y$ denote the position coordinate on the CT image after crack detection of voxel and $Z$ denote the sequence number of the CT image. Let $O$ denote the voxel property. If the voxel is identified as a voxel of crack edges, then the phase property $O$ of the voxel is 1 , otherwise it is 0 . So, in this paper, the storage format for voxels is $(X, Y, Z, O)$ and the results of voxel extraction are shown in Fig. (2).

\subsection{Three-dimensional surface model construction}

For three-dimensional solid model with fine and complex structures, its surface model is represented approximately by network model which consisted of a large number of polygons. At present, the triangle mesh is the most widely used polygon mesh. And in this paper, we
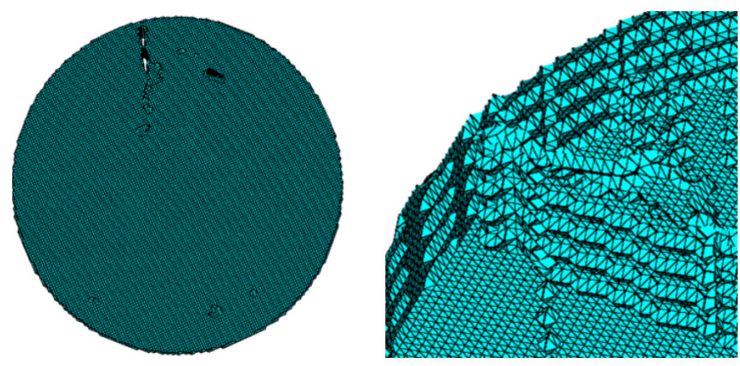

Fig. (3). The complete and sectional three-dimensional surface model for concrete crack.

use the classical Marching Cubes algorithm [10] to construct the triangle mesh of threedimensional surface model for concrete crack based on the voxels which are extracted from CT image. The Marching Cubes algorithm that we adopt is a classical algorithm for triangular meshes construction from voxels which has the advantages of good quality and high efficiency of triangular meshes generation. In addition, the Marching Cubes algorithm has high robustness for mass data processing which is suitable for the three-dimensional surface model construction based on a large amount of voxels [11]. The three-dimensional surface model for concrete crack which is constructed by using Marching Cubes algorithm is consisted of a series of triangle meshes with good quality, as shown in Fig. 3.

\subsection{Three-dimensional finite element model generation}

At present, there are three main types of elements in three-dimensional model generation that include tetrahedron element, octree element and hexahedron element [12]. Among the three elements, it is convenient to construct tetrahedron elements which can recover the complex structure of model better, and moreover, the topological structure of tetrahedron element is simpler and better. Therefore, in this paper we adopt the constrained Delaunay triangulation method based on the triangular meshes of three-dimensional surface model to generate the three-dimensional finite element model which consisted of tetrahedron elements for concrete crack. And the implementation processes of constrained Delaunay triangulation method [13] are as follows:

- Build a large tetrahedron $T$ which contains all vertices of triangular meshes of threedimensional surface model. And sort the vertices $(X, Y, Z, O)$ of triangular meshes in ascending order according to $X$. Let $C$ denote the set which includes the sorted vertices;

- Let $P$ denote vertex that belong to $C$. Insert the vertex $P$ into the tetrahedron $T$ to construct new tetrahedron element until finds 

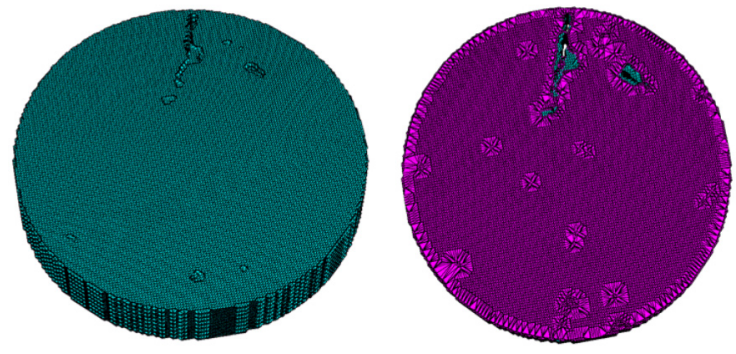

Fig. 4. The complete and sectional three-dimensional finite element model for concrete crack.

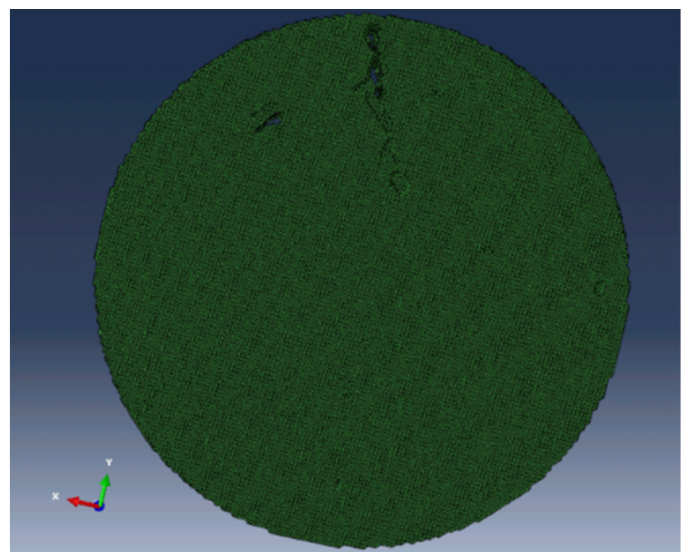

Fig. 5. Three-dimensional finite element model for concrete crack in ABAQUS.

a new tetrahedron element $t$ which inserted vertex $P$ can meet the Delaunay criteria [14];

- Connect vertex $P$ with each vertex of the tetrahedron element $t$ and then store the new tetrahedron elements $T_{P}$ which consisted of the vertex $P$ and vertices of the tetrahedron element $t$ in the Delaunay tetrahedron set $D$;

- Loop executes the second step until all vertices $P$ are inserted into the tetrahedron $T$.

The three-dimensional finite element model for concrete crack is generated by completing the above steps, and the model is shown in Fig. 4 . With reference to Figure 4 we can see that the three-dimensional finite element model for concrete crack has included finite element with good quality which can be used to finite element calculation and analysis directly.

\section{Numerical analysis}

\subsection{The numerical simulation of uniaxial compression test}

In this paper, the three-dimensional finite element model for concrete crack is imported into the FEM software ABAQUS based on data interface which is written in $\mathrm{VC}++$ language by our research group, as shown in Fig. 5.

In this paper, we use the numerical simulation of uniaxial compression test based on the three-dimensional finite element model to

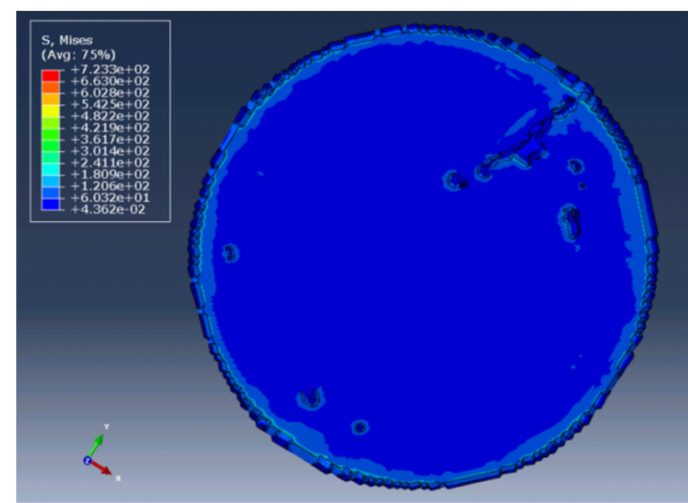

Fig. 6. The von mises nephogram of model.

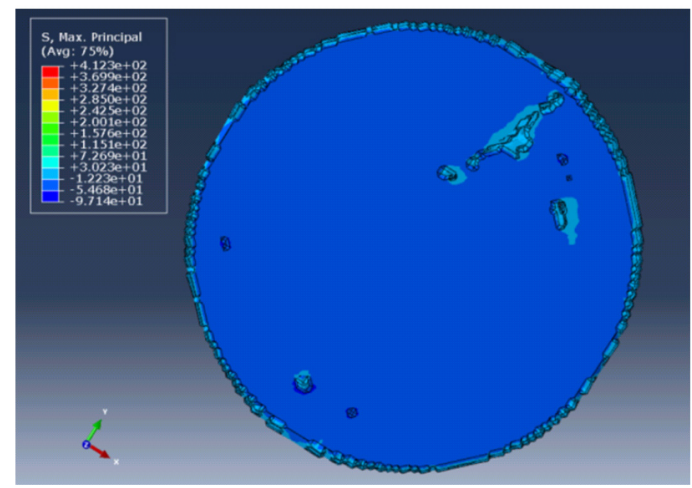

Fig. 7. The max stress nephogram of model.

achieve the analysis of loading for crack regions. According to the experimental data of concrete, the elastic modulus of the concrete is equal to $30 \mathrm{GPa}$ and Poisson's ratio is equal to 0.2 . And the displacement load which is equal to $0.5 \mathrm{~mm}$ is imposed along the $\mathrm{X}$ axes on the upper surface of model and a fixed constraint is imposed on the bottom surface of the model. After the numerical simulation and calculation in ABAQUS, the Von Mises nephogram is shown in Fig. 6, the Von max stress nephogram is shown in Fig. 7, the medium stress nephogram is shown in Fig. 8 and the displacement nephogram along the load direction of the model is shown in Fig. 9.

\subsection{Result Analysis}

With reference to Fig. 6, Fig. 7 and Fig. 8 we can see that the stress distribution of concrete is unbalanced because of the existence of crack regions and pore structures. And there is a phenomenon of stress concentration occurring at crack regions and the edge of pores which has good agreement with the experimental results. And, it is vital to study the loading state of the concrete crack and investigate the development trend of crack in the concrete. 


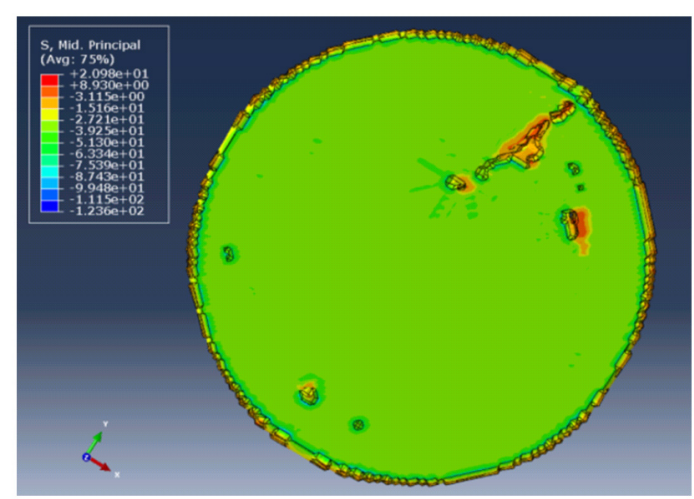

Fig. 8. The medium stress nephogram of model.

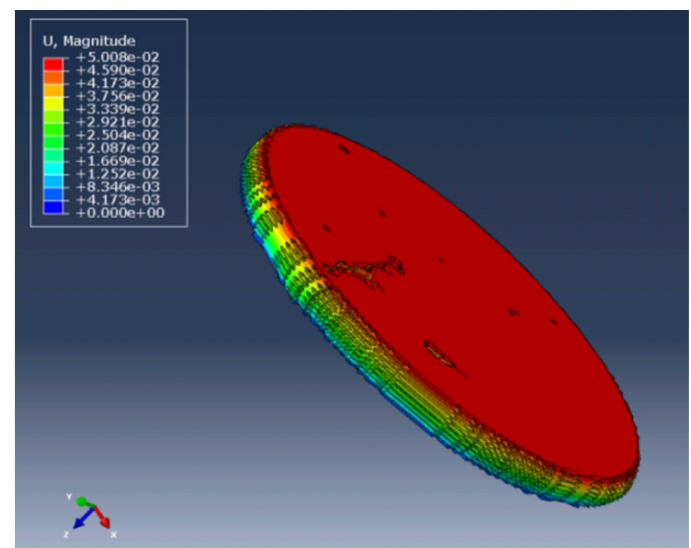

Fig. 9. The displacement nephogram of model.

With reference to Fig. 9 we can see the displacement of the concrete structures is generally maintained layered distribution which changes with the increase of load step when the concrete specimen is not destroyed. The results are in accord with the experimental results which show that the generated three-dimensional finite element model has good consistency with the real concrete in the elastic properties and the stressstrain relationship that can be used to predict mechanical properties of the concrete.

\section{Conclusions}

In this paper, a new generation method of three-dimensional finite element model based on CT image for concrete crack is proposed. The CT images for concrete crack are obtained by using high resolution industrial CT scanning equipment and then segmented by using watershed algorithm. And the three-dimensional sur- face model for concrete crack is constructed by using Marching Cubes algorithm based on voxels extracted from CT image. Taking the threedimensional surface model as a constraint, the three-dimensional finite element model for concrete crack is generated based on constrained Delaunay triangulation algorithm. The threedimensional finite element model is imported into the FEM software ABAQUS based on data interface to achieve the simulation of uniaxial compression test. The results of the numerical simulation are in accord with the physical test which provides a new investigation method for the analysis of loading for crack regions.

\section{Acknowledgements}

This work was financially supported by the national major scientific instrument and equipment development project (No. 2011YQ030112).

\section{References}

1. X. Li, J. A. Wang, S. J. Zhang, J.Xi'an Univer. Scie. Techn.,32, 676. 2012.

2. C. S. Li, D. Zhang, H. X. Wang, S. S. Du, Rock Soil Mech., 35, 2731,2014.

3. H. Q. Chen, W. H. Ding, Y. B. Pu, F. N. Dang, ShuiLi XueBao, 37, 1044, 2006.

4. E. Maire, A. Fazekas, L. Salvo, R. Dendievelb, et.al., Comp. Scie. Techn., 63, 2431, 2003.

5. W. Bai, G. Peng, Y. L. Qi, F. Qian, Concrete, 2, 63, 2008

6. S. L. Hao, F. N. Dang, H. Q. Chen, X. Y. Liang, Concrete, 3, 13, 2009.

7. T. Tang, D. S. Luo, X. H. He, Q. Z. Teng, Comput. Engin.Appl. 7, 227,2005.

8. W. Yang, M. Zhu, M. Z. Li, J. Sichun Univ. 50, 967, 2013.

9. H. Xu, Z. B. Li, Y. Y. Jiang, J. B. Huang, Comp. Engin.Design, 35, 4244, 2013.

10. X. Wang, X. Q. Qin, F. N. Dang, G. Hu, Z. Qu, J. Xi'an Univ.Techn., 25, 477, 2009.

11. S. L. Liu, X. D. Yang, K. Chen, J.Tsinghua Univ., 50, 1214, 2010.

12. S. B. Bi, G. J. Zhang, R. T. Hou and J. T. Liang, J.Wuhan Univ.Techn., 32, 26, 2010.

13. G. Li and Y. X. Zhao, J. Syst. Simul., 19, 3734,2007 .

14. W. G. Guan, Q. Wu, L. P. Jia ,M. H. Liu, J.Huazhong Unive.Scie. Techno, 33, 67,. 2005. 